Crossvergence of socially (ir)responsible employment practices in supplier firms

\begin{tabular}{|l|l|}
\hline Journal & critical perspectives on international business \\
\hline Publication date & 18 September 2019 \\
\hline Vol/No/Pages & $\begin{array}{l}\text { Online first, } \\
\text { https://www.emerald.com/insight/content/doi/10.1108/cpoib-11-2017-0076/full/html }\end{array}$ \\
\hline DOI & $10.1108 /$ cpoib-11-2017-0076 \\
\hline
\end{tabular}

This article is (c) Emerald Group Publishing and permission has been granted for this version to appear on the author's web-profile at the Erasmus University Rotterdam. Emerald does not grant permission for this article to be further copied/distributed or hosted elsewhere without the express permission from Emerald Group Publishing Limited. 


\section{Crossvergence of socially (ir)responsible employment practices in supplier firms}

\section{Structured Abstract:}

Purpose: The purpose of this paper is to introduce the notion of crossvergence from international human resource management (IHRM) as a conceptual lens for understanding and analyzing the formation of socially (ir)responsible employment practices in supplier firms in global production networks (GPNs). The crossvergence perspective can particularly contribute to understanding how the agency of suppliers is influenced by the interaction of global-local dynamics.

Design/Methodology/Approach: The paper illustrates how the formation of socially (ir)responsible employment practices can be understood as a process of crossvergence. Subsequently, it reviews and structures insights from GPN and IHRM literature to detail the process.

Findings: The paper underscores the complicated role of suppliers in ensuring decent work in GPNs. Suppliers face a multitude of global and local interacting, and partially conflicting, demands. They process these demands as active agents and need to develop suitable employment practices in response.

Originality/value: The paper supports the nascent discourse on supplier agency in forming socially responsible employment practices. It connects different streams of literature to illuminate the perspective of suppliers, introduces IHRM insights to the debate, and offers conceptual guidance for analyzing interacting global and local pressures on suppliers.

Keywords: Corporate social responsibility, Labor standards, Decent work, Working conditions, Ethical employment, Convergence, Divergence, Supplier agency, Global production networks, Global value chains, Global supply chains, Private sector development

Paper type: Conceptual paper 


\section{Introduction}

The Sustainable Development Goals of the United Nations (UN, 2015) include "decent work for all" being achieved worldwide by 2030, and the ongoing incidence of labor scandals underscores the importance of this objective. Reports particularly highlight working conditions of suppliers in developing countries that operate in buyer-driven global production networks (GPNs). Five years after the Rana Plaza factory building collapse in 2013 that killed 1,134 garment workers, unsafe factories continue to be reported in Bangladesh (Barrett et al., 2018). In addition, forced labor remains a problem in the Thai fishing industry (Human Rights Watch, 2019), and in the cell phone production chain, child labor in cobalt mining is only one of the labor-related concerns (Hermes EOS, 2017).

What drives the formation of socially irresponsible employment practices in developing country supplier firms? What could motivate responsible practices? The social dimension of work in GPNs is attracting increasing attention in critical debates on international business (IB) (e.g., Khattak et al., 2017; Lee and Gereffi, 2015). Especially GPN scholars address decent work shortcomings and analyze how GPN dynamics affect labor outcomes in supplier firms. First, the impact of globalization and its (negative) influence on employment practices is debated. In particular, global competition is argued to incentivize suppliers to reduce labor standards (Standing, 1999). Second, the design and effectiveness of public and private labor market regulation are analyzed. The existing literature presents a rather bleak outlook and characterizes current regulatory means as insufficient to prevent irresponsible employment practices (Barrientos et al., 2011b; Berliner et al., 2015). Third, the role of the local environment is discussed. Local institutions are commonly characterized as failing to protect workers in developing countries, but they have attracted renewed interest because they can have a positive or negative effect as they interact with global regulatory efforts (Mayer and Gereffi, 2010; Toffel et al., 2015). Fourth, a debate on the role of suppliers is just beginning. GPN scholars discuss opportunities for economic upgrading of suppliers and how these opportunities affect social upgrading (Knorringa and Pegler, 2006), as well as the role of large first-tier suppliers and their influence on labor standards in GPNs (Merk, 2014). Additionally, selected qualitative studies illuminate the perspective of suppliers and their 
motivation (or rejection) for complying with global labor standards (e.g., Fontana and Egels-Zandén, 2018; Perry et al., 2015; Soundararajan and Brown, 2014).

This paper is rooted in this last stream of literature and responds to the observation that there is limited research on corporate social responsibility (CSR) from the supplier perspective, particularly on suppliers' social responsibility for labor (Fontana and Egels-Zandén, 2018; Huq et al., 2014; Perry et $a l ., 2015)$. The paper intends to encourage the creation of a holistic framework to explain the formation of socially (ir)responsible employment practices from the supplier perspective. The few existing frameworks capture only some aspects of the literature outlined above. Yu (2015), for instance, focused on the effectiveness of private codes of conduct. However, private labor market regulation is only one of the factors that affect suppliers and influence their employment practices.

This paper introduces the concept of crossvergence (Ralston, 2008) as a conceptual lens to guide the framework-building process. Crossvergence is used in International Human Resource Management $(\mathrm{IHRM})^{[1]}$ and describes practice formation in IB as follows: Global and local forces meet at the point of the decision-makers in local firms and drive them to design unique, context-specific employment practices in response. The concept captures three ideas that this paper advocates to consider when building a systematic understanding of the formation of socially (ir)responsible employment practices. First, suppliers must consider a complex web of both global and local influences when making employment decisions. Tools capturing this complexity are needed as different influences constantly interact and only in combination can motivate responsible employment decisions (Lund-Thomsen et al., 2016). Second, suppliers design their employment practices. They are active agents who process external influences and respond in their (business) interest (Scott, 2013). A better understanding of supplier agency can help to explain why global and local regulations can be effective for some suppliers but fail for others. Third, for suppliers, many decisions related to the social responsibility of employment practices are simultaneously human resource (HR) decisions (e.g., working hours or wages). However, HR research has rarely been linked to the debate on decent work in GPNs (for a notable exception, see Jayasinghe, 2016). IHRM insights can contribute to the current debate by elucidating how employment practices develop in IB and which factors influence employment decisions. 
The paper will show how the concept of crossvergence can serve as a conceptual lens for analyzing and understanding how suppliers as active agents form socially (ir)responsible employment practices in response to interacting global and local influences. After a brief characterization of GPNs, supplier firms and the social responsibility of employment practices, the crossvergence perspective is introduced in section 3. Section 4 starts detailing the multiplicity of influences on local firms and the agency of suppliers in designing employment responses. Thereby, GPN as well as IHRM findings are considered. 


\section{GPNs, suppliers and their employment practices}

This paper focuses on socially (ir)responsible employment practices in developing country supplier firms embedded in buyer-driven GPNs. A brief characterization of GPNs, supplier firms and the social responsibility of employment practices shall lay the foundation for the subsequent discussion on the crossvergence of employment practices.

\subsection{GPNs}

A GPN refers to "an organizational arrangement, comprising interconnected economic and noneconomic actors, coordinated by a global lead firm, and producing goods or services across multiple geographical locations for worldwide markets" (Coe and Yeung, 2015, pp. 1-2). Many GPNs include production sides in developing countries and are therefore not only discussed as an integral part of international business but also linked to development outcomes (Lee and Gereffi, 2015). For the purpose of this paper, the term GPN was chosen over alternative terms such as "global commodity chain", "global value chain" or "global supply chain" as the GPN approach highlights the network character of production relationships and the agency of the individual actors within the network (Coe et al., 2008).

The GPN approach portrays the involvement of economic and non-economic actors in global production as a network of interconnected relationships. Thereby, it acknowledges that the network does not only encompass vertical and inter-national but also horizontal and intra-national linkages (Coe et al., 2008). The local context of GPN actors frames their behavior and thereby influences GPN dynamics. GPN research is therefore oftentimes called to bridge literatures to foster understanding of the local impact on GPN phenomena as well as the GPN impact on local phenomena. Coe et al. (2004), for instance, bridge works on local institutional structures with works on GPNs to gain a more comprehensive understanding of regional development. Conversely, this paper proposes to bridge works on GPNs with HRM literature to advance understanding of decent work in GPNs.

The GPN approach highlights the importance of analyzing the agency of different actors involved in globally dispersed production networks. It encourages actor-centered research and provides conceptual foundations to build upon, e.g., Yeung and Coe's (2015) dynamic theory of GPNs. Works 
answering to these calls thereby tend to focus on analyzing the agency of buyers, workers and institutions. Supplier agency, and especially the agency of supplier SMEs, is less frequently discussed and awaits further attention (Soundararajan et al., 2018).

\subsection{Different types of suppliers}

Referring to "the suppliers" in GPNs can be misleading because it depicts very different types of companies as belonging to one group. Even within one single industry in one GPN, different types of suppliers can be encountered. Therefore, the heterogeneity of suppliers is addressed in the following and further specified in table 1 .

In GPN research, suppliers are especially differentiated according to their role in the GPN (Nadvi and Raj-Reichert, 2015; Yeung and Coe, 2015) and according to their level of economic upgrading (Lund-Thomsen et al., 2012; Barrientos et al., 2011a). It is discussed in how far the tier-level and product, process or functional sophistication are linked to the design of employment practices. Table I provides an overview of commonly used supplier typologies.

Besides GPN-related characteristics, general characteristics of a company and its internal stakeholders can be used for characterizing different types of suppliers. The list of characteristics that influence a firm's HR strategy is thereby long (see e.g., Jackson et al., 2014). In order not to overload this paper, table I focuses on selected characteristics that have been salient in the decent work debate.

In line with the thematic focus of this paper, the subsequent discussion will especially relate to suppliers struggling to implement socially responsible employment practices, e.g., suppliers in buyerdriven GPNs that offer labor intensive and low skilled production work. The level of analysis can be the individual supplier, or a horizontal network of suppliers showing collective employment practices (see Fontana and Egels-Zandén, 2018 for a discussion of supplier collective behavior). It will be noted that different types of suppliers (or supplier networks) are likely to react differently to global and local influences and chose different employment responses. 


\begin{tabular}{|c|c|c|}
\hline Classification criteria & Different types of suppliers & References \\
\hline \multicolumn{3}{|l|}{ Role in GPN } \\
\hline Tier & - Tier $1 / /$ tier $2 / /$ tier 3 etc. & $\begin{array}{l}\text { Nadvi and Raj-Reichert } \\
(2015)\end{array}$ \\
\hline Degree of specialization & $\begin{array}{l}\text { - Specialized supplier (industry-specific) // } \\
\text { Specialized supplier (multi-industry) // } \\
\text { Generic supplier }\end{array}$ & Yeung and Coe (2015) \\
\hline \multicolumn{3}{|c|}{ Level of economic upgrading within a value chain } \\
\hline Product sophistication & $\begin{array}{l}\text { - High // low brand value of buyer } \\
\text { - High // low product quality } \\
\text { - High // low product complexity }\end{array}$ & $\begin{array}{l}\text { Humphrey and Schmitz } \\
(2002) \\
\text { Barrientos et al. (2011a) }\end{array}$ \\
\hline $\begin{array}{l}\text { Process sophistication: } \\
\text { Technology }\end{array}$ & $\begin{array}{l}\text { - Labor intensive // machine intensive } \\
\text { - Old // standard // progressive technology }\end{array}$ & Lund-Thomsen et al. (2012) \\
\hline $\begin{array}{l}\text { Process sophistication: } \\
\text { Production organization }\end{array}$ & $\begin{array}{l}\text { - Lean manufacturing // Assembly lines } \\
\text { - Home-based work // Factory work }\end{array}$ & $\begin{array}{l}\text { Locke and Romis (2007) } \\
\text { Lund-Thomsen et al. (2012) }\end{array}$ \\
\hline Functional sophistication & $\begin{array}{l}\text { - Low skill content (e.g., assembly) // } \\
\text { high skill content (e.g., design, marketing) }\end{array}$ & $\begin{array}{l}\text { Humphrey } \\
(2002)\end{array}$ \\
\hline
\end{tabular}

\section{Internal stakeholder characteristics}

\begin{tabular}{lll} 
Ownership & $\bullet$ Foreign // local & Akorsu (2011) \\
Employee base & - Migrant // local & Azmeh and Nadvi (2013) \\
& - Female-dominated // male-dominated & Barrientos et al. $(2003)$ \\
& $\bullet$ Formal // informal & \\
Management base & - Foreign // local & Lawler et al. (2011) \\
& - Western // Southern & \\
\hline Organization characteristics & & \\
Business strategy & e.g., Diversification // growth // innovation // & Jackson et al. (2014) \\
Organization size & cost control & \\
Organization culture & e.g., Number of employees & Oka (2010) \\
Life cycle stage & e.g., Clan // adhocracy // hierarchy // market & Cameron and Quinn (2006) \\
& e.g., Start-up // growing // mature // declining & Jackson and Schuler (1995)
\end{tabular}

Table I: Typologies of suppliers 


\subsection{Socially (ir)responsible employment practices}

Contributing to the decent work debate, this paper focuses on the social responsibility of suppliers' employment practices. Employment practices refer to the organizational rules and activities by which people are employed and managed. The specification socially (ir)responsible highlights that employment practices are discussed under ethical considerations. Drawing on definitions of ethical HRM, socially responsible practices are understood in this paper as practices that cater to the well-being of employees (Armstrong and Taylor, 2014).

Even though the understanding of what is "responsible" is considered highly context specific (Burchell et al., 2014), there is an increasing consensus in the international debate that certain employment practices are irresponsible and should be prohibited. The responsibility of employment practices is therefore frequently defined in reference to global labor standards intending to prohibit inhuman or irresponsible practices. Empirical studies on the social responsibility of employment practices following this operationalization distinguish between compliant and noncompliant practices. The reality of suppliers is, however, more complex. Soundararajan and Brown (2014) find that firms often interpret standards based on their own assumptions and expectations and point to the existence of various shades of grey between compliance and noncompliance. Furthermore, suppliers can implement practices that go beyond compliance. Most definitions of CSR even stress the voluntary nature of socially responsible behavior (e.g., van Marrewijk, 2003). The social responsibility of employment practices is therefore depicted as a multi-point scale in figure 1 (vertical axis).

It is beyond the scope of this paper to concretely discuss different forms of employment practices and their responsibility (e.g., design of salary systems, organization of working times). However, the multi-dimensionality of the construct shall be highlighted. Suppliers can choose different levels of responsibility depending on the employment dimension concerned. Barrientos and Smith (2007) show, for example, that suppliers react differently to so-called outcome standards (e.g., health and safety, wages, working hours) in comparison with process standards such as the freedom of association and collective bargaining. 
Figure 1 illustrates this paper's understanding of socially (ir)responsible employment practices. It was designed in consideration of the author's field experience and depicts examples of three suppliers. The vertical axis proposes to tread the social responsibility of employment practices as a multi-point, or even continuous, variable. The horizontal axis depicts the multi-dimensionality of the concept. Various patterns of socially (ir)responsible employment practices can therefore result from the process of crossvergence that will be outlined in the remainder of this paper.

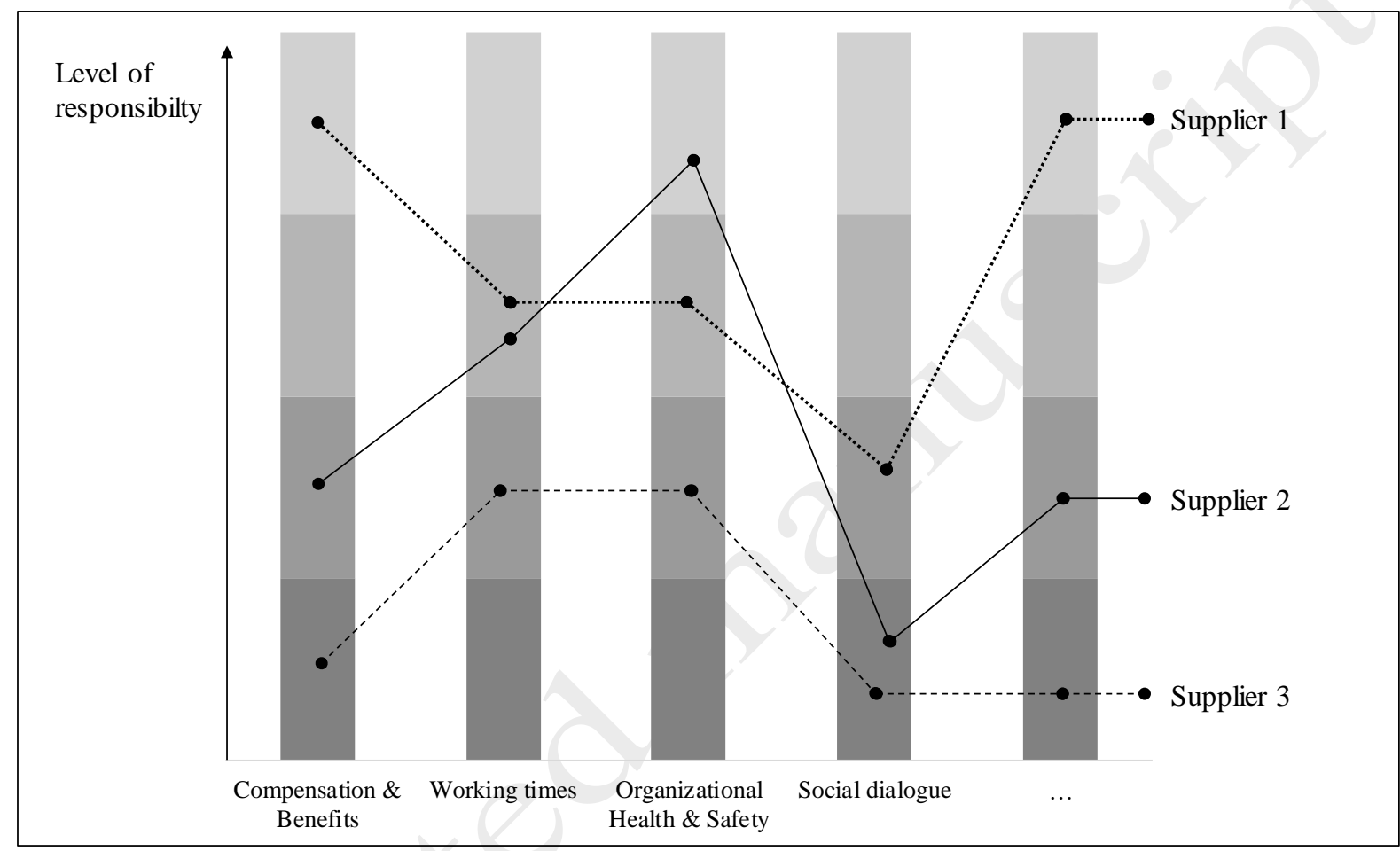

Figure 1: Exemplary patterns of socially (ir)responsible employment practices

Source: Author's own analysis 


\section{The formation of socially (ir)responsible employment practices as a result of crossvergence}

Imagine four suppliers producing garments for the fictional brand STAR. The four suppliers are of a similar size, produce similar products, and operate in countries with similar labor laws. They are all subject to STAR's code of conduct. Supplier A is a first-tier supplier operating in a country with strong institutions. Supplier B, another first-tier supplier, operates in a country with weak institutions. Supplier C, a second-tier supplier, operates in the same country. Supplier D, also a second-tier supplier, operates in the country with strong institutions. STAR's code of conduct as well as national laws cap working hours at maximal 60 hours per week, including overtime.

What do working hours look like in the four firms? Looking at the suppliers' roles in the GPN as well as the strength of local institutions, the shortest hours would be expected at supplier A, and the longest hours at supplier $\mathrm{C}^{[2]}$ Would this assumption change by looking through the crossvergence lens? Maybe, because no assumption could be made without asking further questions, e.g.: What working times arrangements do workers demand? How strong is their negotiating power? How high are fixed costs for labor? What are the consequences of non-compliance with global or local regulatory demands? How risk affine is the supplier? The results of the example show the relevance of these questions: Supplier B and C operate 48 hours per week because their local female labor base refuses to work more hours due to family obligations. Supplier D operates 72 hours per week. Fixed labor costs are high, sales prices of second-tier suppliers are low, and the supplier considers excessive hours inevitable to remain profitable. Supplier A in comparison complies with the maximal 60 hours per week. First-tier suppliers are regularly audited by STAR and the supplier fears to lose them as a customer if non-compliance is detected.

The example illustrates the complexity of understanding the social responsibility of employment practices in GPNs. Global, local and business considerations come together and lead to different types of employment responses. The notion of crossvergence is introduced in the following as a conceptual lens to capture this complexity and to understand how the agency of suppliers is influenced by their global and local environment. 
The idea of crossvergence arose in the convergence-divergence debate in IB. Convergence advocates (e.g., Kerr et al., 1960; Levitt, 1983; Prentice, 1990) argued that due to globalization, business environments become similar worldwide and 'best' practice HR experiences travel around the globe. Divergence advocates however highlight that differences in HRM will prevail across countries, and explain these differences with the help of institutional theories (Wood and Horwitz, 2015; Wood et al., 2012) and cultural theories (Reiche et al., 2012; Jackson, 2015). Ralston (2008) points out that converging and diverging pressures meet at the point of the individual local firm. Firms are simultaneously impacted by global and local dynamics, and their agency determines how these dynamics translate into employment practices (Winchester and Bailey, 2012).

Applying the idea of crossvergence to the case of suppliers in GPNs, the process can be pictured as follows: As exporters, suppliers are subject to global competition and global regulatory demands. Global competition often translates into price, time and quality pressure. Global (public and private) regulatory demands set responsibility benchmarks for HR decisions. As local firms, suppliers are influenced by their local institutional, socio-cultural and industry environment. Local institutions, especially labor laws, delimit the scope for HR decision-making. Local culture shapes values and beliefs about business, work and ethics. And the way business is done in the industry serves as reference for HR decisions. These influences come together at the point of the supplier and are (consciously or unconsciously) processed at this point. Suppliers for instance weigh costs and benefits of different employment responses, decide depending on risk considerations, or orient themselves at the local industry benchmark. The salience of different drivers for suppliers' decision-making thereby depends on the supplier characteristics discussed in the second section of this paper. Large multi-national suppliers might be in a position to negotiate decent lead times and prices, second-tier suppliers might not be audited for labor standard compliance, and firms working with a migrant labor base might consider local culture as irrelevant for their employment decisions. Depending on the suppliers' active processing of global-local dynamics, different forms of employment patterns evolve.

The notion of crossvergence puts suppliers in the focus of the analysis when trying to understand decent work shortcomings, or how to better promote responsible employment practices in GPNs. It can serve as a conceptual lens to understand how supplier agency is influenced by interacting global and 
local influences. Figure 2 outlines the overall process of crossvergence as described above. The different elements of the process will be further specified in the next section of this paper.

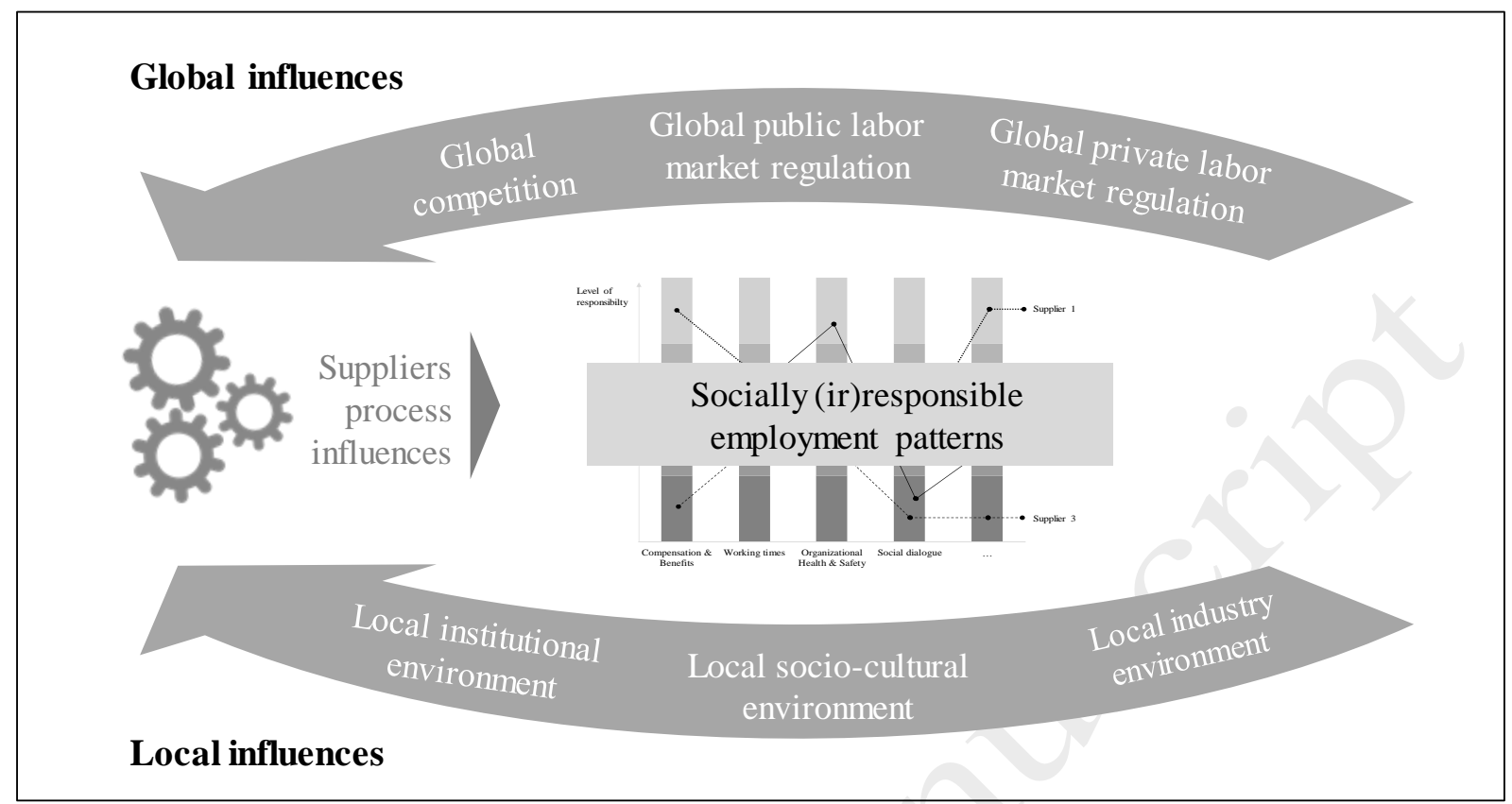

Figure 2: Crossvergence of socially (ir)responsible employment practices 


\section{Detailing the process of crossvergence}

Existing empirical research as well as the reviews of Vogel (2008), Mayer and Gereffi (2010), Barrientos et al. (2011b), Berliner et al. (2015), and Lund-Thomsen et al. (2016) provide significant insights into global and local influences on employment practices in GPNs. Yu (2015) furthermore summarized factors influencing the effectiveness of private codes of conduct. The following analysis uses the notion of crossvergence to systemize and extend existing research insights from GPN and IHRM literature. For this purpose, the literature on GPN and IHRM was reviewed and external global and local influences were identified and clustered, using the qualitative research software MAXQDA. IHRM literature especially extended insights from GPN literature on local influences. The processing of interacting global and local influences at the point of the supplier is discussed in the last part of the section.

\subsection{Global influences}

Three global influences on suppliers are discussed in the literature: global competition, global public labor market regulation, and global private labor market regulation.

Standing (1999) postulates that global competition has led to converging employment practices that are characterized by income insecurity, employment insecurity, low pay, longer working hours, increased female participation, and job specialization. Davies and Vadlamannati's (2013) longitudinal study of labor practices in 135 developing and developed countries empirically supports this and concludes that competition for foreign investments leads to reduced enforcement of labor laws and convergence to low levels of responsibility.

To counter the trend of declining responsibility, global standards set by the International Labor Organization (ILO), by international finance institutions, and in trade agreements harmonize national labor laws and policies and lead to a converging framework of labor market regulation across borders. However, convergence oftentimes stops at the regulatory framework, with most empirical studies showing that suppliers' actual compliance with global labor standards lags far behind official national regulations (Stallings, 2010; Caraway, 2010). 
The limits of public regulatory efforts in GPNs sparked the debate on labor market regulation through private initiatives of large multinational enterprises (MNEs), especially from the Global North. A comparison of the different sets of private labor standards reveals directional convergence for general principles such as prohibitions against child labor, forced labor, discrimination, and excessive working hours as well as the right to organize and the rights for security and occupational health and safety. Nevertheless, private regulation fails to achieve full convergence (Barrientos et al., 2011b; Locke et al., 2013; Berliner et al., 2015) because not all suppliers are subject to private labor standards and comprehensive enforcement fails due to information asymmetries and conflicts of interests.

Table II starts detailing the concepts of global competition, global public regulation and global private regulation in order to illustrate which characteristics of these global trends have especially been discussed to influence the social responsibility of employment practices in supplier firms. 


\begin{tabular}{|c|c|}
\hline Influences & References (selected) \\
\hline $\begin{array}{l}\text { Global competition } \\
\text { - Price pressure - Pressure of lead firms on supplier to keep } \\
\text { sales prices as low as possible } \\
\text { - Lead time pressure - Pressure of lead firms on supplier to } \\
\text { deliver the order in short lead times } \\
\text { - Flexibility pressure - Pressure of lead firm on supplier to } \\
\text { flexibly respond to production demands } \\
\text { - Quality pressure - Pressure of lead firms on suppliers to } \\
\text { adhere to product quality specifications }\end{array}$ & $\begin{array}{l}\text { Chan and Ross (2003), Davies } \\
\text { and Vadlamannati (2013), } \\
\text { Dhanarajan (2004), Greer and } \\
\text { Hauptmeier (2016), Perry et } \\
\text { al. (2015), Rodgers (2007), } \\
\text { Standing (1999), } \\
\text { Tjandraningsih (2013), Tokatli } \\
\text { et al. (2008) }\end{array}$ \\
\hline $\begin{array}{l}\text { Global public labor market regulation and initiatives } \\
\text { - } \quad \text { Global public labor standards } \\
-\quad \text { set by ILO } \\
-\quad \text { set by international finance institutions } \\
-\quad \text { integrated in trade agreements } \\
\text { - Technical assistance - Projects of international organizations } \\
\text { offering support to suppliers } \\
\text { - Activist pressure - Labor-related campaigns of global unions, } \\
\text { non-governmental organizations (NGOs), and the media }\end{array}$ & $\begin{array}{l}\text { Anner (2001), Brown (2016), } \\
\text { Caraway (2010), Ebert } \\
\text { (2016), Hafner-Burton and } \\
\text { Tsutsui (2005), MacIntosh } \\
\text { (2013), Rossi (2015), } \\
\text { Schrank (2013), Siroën } \\
\text { (2013), Stallings (2010), } \\
\text { Tsogas (2001) }\end{array}$ \\
\hline
\end{tabular}

\section{Global private labor market regulation and initiatives}

- Global private labor standards

- Buyer codes of conduct

- Industry standards and labels

- Multi-stakeholder standards and labels

- International framework agreements

- Audit regimes

- Buyer audits

- Third-party audits

- Buyer-Supplier Cooperation - Activities of buyers offering support to suppliers (e.g., capacity building)
Barrientos and Smith (2007), Bartley and Egels-Zandén (2015), Christian (2017), Donaghey et al. (2014), He and Perloff (2013), Locke et al. (2007), Locke and Romis (2010), Nadvi and Wältring (2002), Oka (2010), Porteous et al. (2015), Sartor et al. (2016), Schuster and Maertens (2016)

Table II: Global influences 


\subsection{Local influences}

IHRM scholars distinguish between local institutional and socio-cultural influences on suppliers (Fan et al., 2016) and also highlight the importance of the industry environment of local firms. Local influences are also discussed in the GPN debate, especially the need to view global regulatory efforts in local settings or putting "codes in context," as Toffel et al. (2015, p. 205) phrase it.

From an institutionalist perspective, political and legal institutions shape the behavior of organizations. The effectiveness of employment practices depends on their fit with local institutional contexts (Sparrow et al., 1994). Looking at the institutional side in the context of GPNs, scholars show that among other factors, stringent national labor legislation (Frenkel, 2001), press freedom (Toffel et al., 2015), independent workers' institutions (Frenkel, 2001), and state regulatory capacity (Locke et al., 2013) can incentivize suppliers to improve their employment practices. Local institutions, however, do not always have a positive impact. First, domestic institutions in the Global South are often considered too weak to ensure socially responsible employment practices in GPNs (Mayer and Gereffi, 2010). Second, domestic institutions can conflict with private labor market regulation and therefore impede their effectiveness (Locke et al., 2013; Lund-Thomsen et al., 2012).

Discussing the impact of the socio-cultural environment on employment practices, IHRM researchers find that values, assumptions, and beliefs of decision-makers shape local HR policies and practices (Briscoe and Schuler, 2004). Especially gender discrimination in employment is frequently attributed to socio-cultural assumptions about gender roles. The World Bank (2013) for instance links the practice to pay male workers more than female workers in the Middle East to the local assumption that men have to financially provide for their families. Even though the socio-cultural context of suppliers receives less attention in the GPN debate, works discussing labor agency in GPNs (e.g., Coe and Hess, 2013), as well as qualitative studies on suppliers acknowledge its importance. Soundararajan and Brown (2014) and Perry et al. (2015) emphasize, for instance, that cultural values can conflict with or motivate responsible employment practices. 
HRM scholars highlight the need to consider industry characteristics as an antecedent of employment practices (Jackson and Schuler, 1995). Thereby, especially local industry characteristics are of importance as industry characteristics can differ significantly across contexts. Lund-Thomsen et al. (2012), for instance, show that machine stitching of footballs in factories is common in China, while footballs are stitched in home-based settings in Pakistan. Evaluating the impact of the industry environment on employment practices, GPN scholars especially discuss the locally dominant production regime (Lund-Thomsen et al., 2012) and the available labor base. Azmeh (2014) shows in his study on the Egyptian and Jordanian garment industry that the social embeddedness of workers significantly affected labor regimes in that industry.

Table III starts detailing local institutional, socio-cultural and industry influences on suppliers but cannot be considered comprehensive. Especially insights from IHRM literature await validation in the context of GPNs. 


\begin{tabular}{|c|c|}
\hline Influences & References (selected) \\
\hline 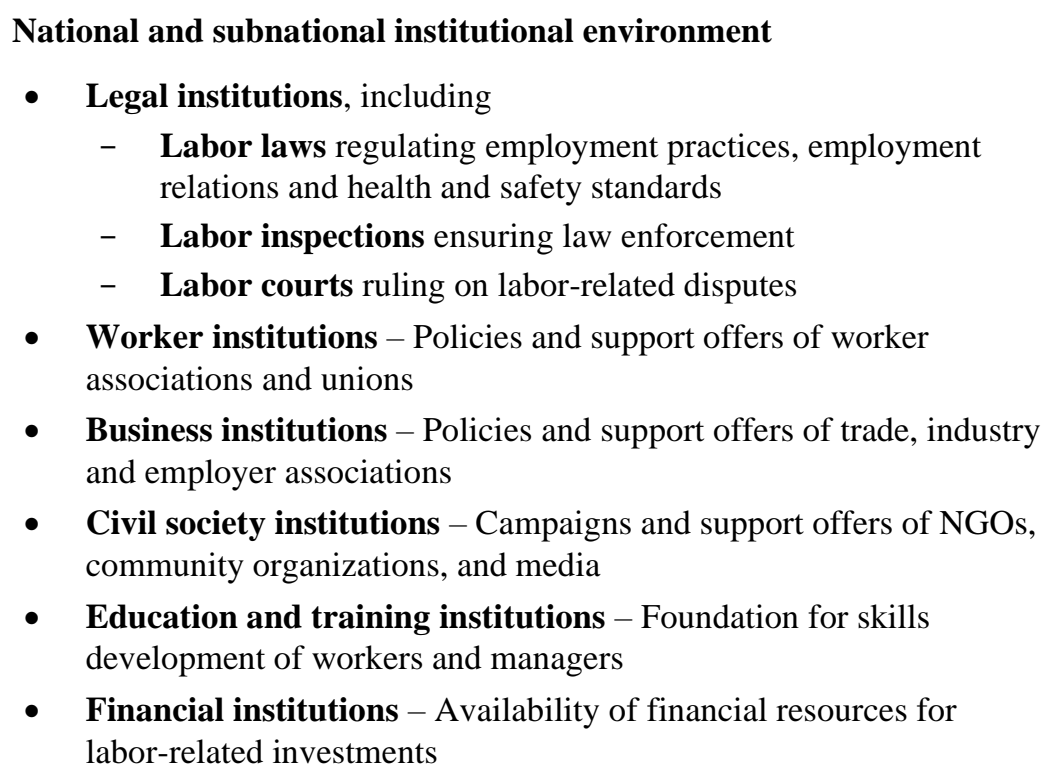 & $\begin{array}{l}\text { Ali and Jadoon (2012), } \\
\text { Amengual (2014), Budhwar } \\
\text { and Sparrow (2002), Cooke } \\
\text { (2004), Frenkel (2001), } \\
\text { Knorringa and Nadvi (2016) } \\
\text { Locke } \text { et al. (2013), } \\
\text { MacIntosh (2013), Ronconi } \\
\text { (2010), Schrank (2013), } \\
\text { Sparrow et al. }(1994), \\
\text { Toffel } \text { et al. } \text { (2015) }\end{array}$ \\
\hline
\end{tabular}

\section{National and subnational socio-cultural environment}

- Local culture - Distinctive values, assumptions and beliefs shared by the local community, e.g., regarding following dimensions proposed by Hofstede (2011):

- Power distance

- Individualism versus collectivism

- Masculinity versus femininity

- Uncertainty avoidance

- Long-term versus short-term orientation

- Indulgence versus restraint

Auchter and Dziewa (2013), Briscoe and Schuler (2004), Chandrakumara and Sparrow (2004), Huq et al. (2014), Malik (2007), Metters (2017), Perry et al. (2015), Punia and Sharma (2015), Soundararajan and Brown (2014)

- Value of Corporate Social Responsibility (CSR) - The value a society attributes to socially responsible behavior of local companies

- Definition of labor-related CSR - Local definition of socially responsible employment practices

- Gender norms - Local definition of how women and men should behave and be treated

\section{National and subnational industry environment}

- Labor markets - Characteristics of the available labor force (e.g., size, skill level, and nationality)

- Competitors - Characteristics of local competition (e.g., intensity, degree of cooperation, CSR standards)

- Industry reputation - The labor-related CSR reputation of the local industry

- Technology - The standard type of technology and degree of automatization used in the local industry

- Production process - The standard production process used in the local industry

Ali and Jadoon (2012), Azmeh (2014), Bartley (2010), Budhwar and Sparrow (2002), Donaghey et al. (2014), Huq et al. (2014), Jiang et al. (2012), Lund-Thomsen et al. (2012), Punia and Sharma (2015), Yang and Gallagher (2017)

\section{Table III: Local influences}




\subsection{Processing of interacting global and local influences}

A distinctive feature of crossvergence is that it highlights the impact and simultaneous dynamic interaction of converging as well as diverging forces. This characteristic of crossvergence fits well to recent developments in the debate on decent work in GPNs. Lund-Thomsen et al. (2016, p. 11) claim an "emerging consensus that the combination of different drivers, rather than any single factor alone, produces socially and environmentally responsible behavior." Not only global-local interactions have thereby to be considered but also global-global interactions because global stakeholders in GPNs do not speak with one voice.

Different insights on the impact of global-local interactions can be found in the debate on decent work in GPNs. While Nadvi and Wältring among others feared in 2002 that global labor market regulation would weaken national efforts, more recent works indicate that global and local demands need to be aligned in order to enhance the effectiveness of global regulation (e.g., Mayer and Gereffi, 2010). The impact of local institutions is thereby the focus of the debate. Toffel et al. (2015) prove in a quantitative study across different countries and industries that domestic legal institutions significantly influence suppliers' compliance with private standards. Protective laws governing collective labor rights and press freedom reduce labor violations in social audits. A few qualitative studies additionally indicate an interaction of the local socio-cultural environment with the implementation of global standards. In their research on a knitwear-exporting cluster in India, Soundararajan and Brown (2014) report complaints by local managers that lead firms' understanding of labor standards does not necessarily match their own understanding and experience. This disconnect compromised the managers' willingness to comply with private regulatory demands. Characteristics of the local industry and their interaction with global standards are addressed in quantitative studies on the effectiveness of private labor standards. Bartley and Egels-Zandén (2015) and He and Perloff (2013) include industry characteristics as control variables in their research designs.

Global-global interactions cause significant strain for local suppliers because global advocates of a competitive market and global advocates of social standards frequently have conflicting demands. On a public regulatory level, Stallings (2010) and Caraway (2010) show that global pressure for labor 
standards exists in parallel with global pressure for the flexibility of labor markets, and these pressures partially contradict each other. On a private regulatory level, scientists and practitioners warn that compliance with international labor standards is hampered by lead firms' demands for decreases in price and lead time (Oka, 2010; Lund-Thomsen et al., 2012). A supervisor in China vividly summarizes the resulting conflict for suppliers: "The foreigners put us in a trap. On the one hand, they talk about human rights, but on the other hand, they also want good products cheaply. For that, they have to trade of human rights. It is quite obvious" (Ngai, 2005, p. 108).

The notion of crossvergence points to the opportunity to use theories about actor decision-making to advance understanding of interaction effects. The concept highlights that drivers of convergence and divergence join at the point of the individual (Ralston, 2008). Decision-makers (consciously or unconsciously) process the different drivers and make their socially (ir)responsible employment decisions. Different theories exist on how decisions are made in organizations. In the context of GPNs, transaction-cost theory and legitimacy theory have been used to explain decision-making in lead firms (Huq et al., 2014; Anner, 2012) but have yet to be applied to the context of suppliers. In particular, legitimacy theory seems likely to be able to provide theoretical guidance since it is frequently used to explain CSR-related firm agency (Bhattacharyya, 2014). The theory postulates that firm decisionmakers use legitimacy considerations as (one) basic principle when making strategic, especially CSRrelated, decisions. Legitimacy is thereby achieved when firm actions are congruent with the norms, values, beliefs, and definitions of the larger society (Suchman, 1995).

Other starting points for identifying basic principles guiding decision-making in supplier firms can be found in Yeung and Coe's (2015) dynamic theory of GPNs. The theory includes a debate on causal conditions that guide decisions in GPNs and that can influence different actors, including suppliers. The authors discuss "competitive considerations" and "risk considerations" as basic principles for actor decision-making in GPNs (Yeung and Coe, 2015, p. 34). Yeung and Coe's theory was not designed for understanding suppliers' employment decisions but for generally explaining actor-specific strategies in GPNs. Looking at empirical studies on employment practices of suppliers, however, the ideas included in the framework, especially regarding competitive considerations, correspond to existing research findings. Khara and Lund-Thomsen (2012) conclude that suppliers' decisions on labor standard 
implementation depend on what they perceive to be economically efficient for their business operations. Stigzelius and Mark-Herbert (2009) explicitly refer to expected business benefits, market access considerations, and financial risks and restraints as facilitators of supplier behavior.

Future research could show how suppliers' responses to interacting global and local influences are guided by legitimacy, competitive or risk considerations. Thereby, the differentiation of supplier types and employment dimensions discussed in the second section of this paper ought to be considered. Taking risk considerations as an example, first-tier suppliers commonly face a significant higher risk of being audited by lead firms than second-tier suppliers (Posthuma, 2010) and the risk of losing workers due to Health and Safety breaches is often significantly lower than losing them due to unattractive working hours. 


\section{Conclusion}

This paper introduced crossvergence as a conceptual lens to capture the complexity of interacting global and local influences on suppliers, and to analyze the agency of suppliers in navigating this complexity. It furthermore started structuring existing research findings to detail the crossvergence of socially (ir)responsible employment practices. With this effort, the paper intends to aid the creation of a framework that explains the formation of socially (ir)responsible employment practices in GPNs from the supplier perspective. The remainder of this conclusion reflects on this paper's contribution to the debate on global-local interactions in GPNs, its contribution to the nascent discourse on supplier agency, and the benefit of understanding employment decisions of suppliers for advancing the UN's goal of decent work for all

The GPN approach highlights the importance of not only considering vertical but also horizontal linkages in the analysis of network dynamics and outcomes in global production. The crossvergence process presented in this paper confirms this claim for the analysis of employment outcomes. Considering the local institutional, socio-cultural and industry environment of suppliers is crucial for understanding the social responsibility of their employment practices. The quest to specify the crossvergence process thereby indicated the need to bridge literatures to advance understanding of horizontal linkages in GPNs. This paper particularly benefitted from using IHRM insights to supplement the discussion on local influences on suppliers' employment practices and their interaction with global dynamics. Reviewing the literature, thereby, revealed further potential of IHRM to contribute to the debate on decent work in GPNs which went beyond the scope of this paper. Insights on HRM in MNEs may contribute to the analysis of global-local interactions since subsidiaries like suppliers need to apply globally defined standards in a local context. Results from comparative analyses of HRM furthermore elucidate how domestic firms make employment decisions in different parts of the world, including the Global South. Thereby, it remains to be tested whether HR practices of suppliers in GPNs have more in common with the employment practices of local MNE subsidiaries or those of domestic firms. Bridging literatures proved for the topic of employment practices promising to advance understanding of the local embedding of global networks. 
The GPN approach encourages actor-centered research to advance understanding of GPN dynamics and outcomes, especially supplier agency awaits further attention. This paper discussed the agency of suppliers in processing global and local influences, and in designing employment responses. The crossvergence perspective particularly points to the opportunity to use theories about actor decisionmaking to further unpack suppliers' processing of global and local influences. Legitimacy, competitive or risk considerations can guide their employment responses. When discussing supplier agency, it needs to be noted that suppliers are-not only on the receiving end of global and local demands. As active agents, they respond to external influences and shape them in return. First, the agency of (first-tier) suppliers determines in how far global labor standards are implemented in the suppliers' own supply chain (Wilhelm et al., 2016). Second, the agency of (clusters/ networks of) suppliers can impact the contours of global governance structures in GPNs (Knorringa and Nadvi, 2016). Crossvergence cannot be considered a unidirectional or a one-time process. Instead, a dynamic bidirectional relationship between external influences and supplier responses exists. The dynamic nature of crossvergence is recommended to be addressed in future research because the responsibility of employment practices in the long run depends on how suppliers react to external influences.

The development of a framework that explains the formation of employment practices from the suppliers' perspective is advocated in this paper as a starting point to identify new ways to promote socially responsible employment practices despite unfavorable circumstances. More research on supplier agency can for instance help to develop incentives for suppliers to act responsibly. An exemplary thought experiment will illustrate this idea. If future research shows that cost-capability considerations primarily guide supplier agency, suppliers' cost-capability ratios for socially responsible employment practices need to be optimized to achieve the UN's goal of decent work for all. Theoretically, responsible practices do not need to be an economic burden for suppliers. Reviews of the business benefits of CSR (Carroll and Shabana, 2010; Homburg et al., 2013) as well as research on the link between strategic HRM and business performance (Sheehan, 2014; Sels et al., 2006) suggest that suppliers might be incentivized to promote socially responsible employment practices for their own economic profit. Jayasinghe (2016) finds first empirical evidence for this suggestion in Sri Lanka. If future research can identify socially responsible and economically beneficial employment practices as 
well as suitable capacity-development tools supporting suppliers in the implementation of these practices, supplier agency might become another force next to buyer, labor, and government agency promoting socially responsible employment practices in GPNs.

To qualify this rather optimistic outlook on the role of suppliers, it needs to be noted that the implementation of socially responsible employment practices is not likely to benefit all suppliers in GPNs - as is the case for lead firms' CSR practices. The focus on supplier agency is therefore advocated as a supplement to the existing focus on lead firm agency, labor agency, and government agency, not as a substitute. The paper thereby supports Ponte and Sturgeon's (2014, p. 196) notion of a "modular theory-building approach" and introduces the concept of crossvergence as a conceptual lens to advance the module on supplier agency. 


\section{Endnotes}

1 This paper's understanding of IHRM follows the broad definition of Stahl and Bjorkman (2006, p. 1) which "covers all issues related to the management of people in an international context [including] human resource issues facing MNCs in different parts of their organisations [and] comparative analyses of HRM in different countries."

2 The assumption is based on following research findings: The pressure to comply with labor standards is higher for first-tier than for second-tier suppliers (Mares, 2010; Posthuma, 2010). Strong institutions, e.g., in the form of press freedom (Toffel et al., 2015), independent workers' institutions (Frenkel, 2001), or state regulatory capacity (Locke et al., 2013) incentivize suppliers to improve their employment practices. 


\section{References}

Akorsu, A.D. (2011), "Labour standards application among Multinational and Domestic firms in Ghana's Manufacturing Sector", Ekonomski Anali / Economic Annals, Vol. 56 No. 189, pp. 51-68.

Ali, Q. and Jadoon, M.Z.I. (2012), "Towards an Indigenous Perspective on HRM: A study of textile industry of Pakistan", International Journal of Management and Organizational Studies, Vol. 1 No. 2, pp. 44-52.

Amengual, M. (2014), "Pathways to Enforcement. Labor Inspectors Leveraging Linkages with Society in Argentina", ILR Review, Vol. 67 No. 1, pp. 3-33.

Anner, M. (2001), "The International Trade Union Campaign for Core Labor Standards in the WTO", WorkingUSA, Vol. 5 No. 1, pp. 43-63.

Anner, M. (2012), "Corporate Social Responsibility and Freedom of Association Rights: The Precarious Quest for Legitimacy and Control in Global Supply Chains", Politics \& Society, Vol. 40 No. 4, pp. 609-644.

Armstrong, M. and Taylor, S. (2014), Armstrong's handbook of human resource management practice, 13th ed., Kogan Page, London, Philadelphia.

Auchter, L. and Dziewa, M. (2013), "Managing ethical issues. How ISCT can help to fight corruption and child work - A comparative study", Journal of Business and Retail Management Research, Vol. 7 No. 2, pp. 1-14.

Azmeh, S. (2014), "Labour in global production networks. Workers in the qualifying industrial zones (QIZs) of Egypt and Jordan", Global Networks, Vol. 14 No. 4, pp. 495-513.

Azmeh, S. and Nadvi, K. (2013), “'Greater Chinese' Global Production Networks in the Middle East: The Rise of the Jordanian Garment Industry", Development and Change, Vol. 44 No. 6, pp. 1317 1340.

Barrett, P., Baumann-Pauly, D. and Gu, A. (2018), "Five Years After Rana Plaza: The Way Forward", available at:

https://static1.squarespace.com/static/547df270e4b0ba184dfc490e/t/5ac9514eaa4a998f3f30ae13/1 523143088805/NYU+Bangladesh+Rana+Plaza+Report.pdf.

Barrientos, S., Dolan, C. and Tallontire, A. (2003), "A Gendered Value Chain Approach to Codes of Conduct in African Horticulture”, World Development, Vol. 31 No. 9, pp. 1511-1526.

Barrientos, S., Gereffi, G. and Rossi, A. (2011a), "Economic and social upgrading in global production networks. A new paradigm for a changing world", International Labour Review, Vol. 150 No. 3-4, pp. 319-340.

Barrientos, S., Mayer, F., Pickles, J. and Posthuma, A. (2011b), "Decent work in global production networks. Framing the policy debate", International Labour Review, Vol. 150 No. 3-4, pp. $297-$ 317.

Barrientos, S. and Smith, S. (2007), "Do workers benefit from ethical trade? Assessing codes of labour practice in global production systems", Third World Quarterly, Vol. 28 No. 4, pp. 713-729.

Bartley, T. (2010), "Transnational Private Regulation in Practice. The Limits of Forest and Labor Standards Certification in Indonesia", Business and Politics, Vol. 12 No. 03, pp. 1-34.

Bartley, T. and Egels-Zandén, N. (2015), "Responsibility and neglect in global production networks: the uneven significance of codes of conduct in Indonesian factories", Global Networks, Vol. 15 No. s1, pp. 21-44.

Berliner, D., Greenleaf, A.R., Lake, M., Levi, M. and Noveck, J. (2015), "Governing Global Supply Chains: What We Know (and Don't) About Improving Labor Rights and Working Conditions", Annual Review of Law and Social Science, Vol. 11 No. 1, pp. 193-209.

Bhattacharyya, A. (2014), "Managerial attitude and support for social responsibility through the lens of legitimacy theory - a cross country comparison", Social Responsibility Journal, Vol. 10 No. 4, pp. 716-736. 
Briscoe, D.R. and Schuler, R.S. (2004), International human resource management: Policy and practice for the global enterprise, Routledge global human resource management series, 2nd ed., Routledge, London, New York.

Brown, R.C. (2016), "Promoting labour rights in the global economy. Could the United States' new model trade and investment frameworks advance international labour standards in Bangladesh?", International Labour Review, Vol. 155 No. 3, pp. 383-406.

Budhwar, P.S. and Sparrow, P.R. (2002), "An integrative framework for understanding cross-national human resource management practices”, Human Resource Management Review, Vol. 12 No. 3, pp. 377-403.

Burchell, B., Sehnbruch, K., Piasna, A. and Agloni, N. (2014), "The quality of employment and decent work. Definitions, methodologies, and ongoing debates", Cambridge Journal of Economics, Vol. 38 No. 2, pp. 459-477.

Cameron, K.S. and Quinn, R.E. (2006), Diagnosing and changing organizational culture: Based on the competing values framework, The Jossey-Bass business \& management series, Rev. ed., Jossey-Bass, San Francisco, CA.

Caraway, T.L. (2010), "Labor Standards and Labor Market Flexibility in East Asia", Studies in Comparative International Development, Vol. 45 No. 2, pp. 225-249.

Carroll, A.B. and Shabana, K.M. (2010), "The Business Case for Corporate Social Responsibility. A Review of Concepts, Research and Practice”, International Journal of Management Reviews, Vol. 12 No. 1, pp. 85-105.

Chan, A. and Ross, R.J.S. (2003), "Racing to the Bottom. International Trade without a Social Clause", Third World Quarterly, Vol. 24 No. 6, pp. 1011-1028.

Chandrakumara, A. and Sparrow, P. (2004), "Work orientation as an element of national culture and its impact on HRM policy-practice design choices. Lessons from Sri Lanka”, International Journal of Manpower, Vol. 25 No. 6, pp. 564-589.

Christian, M. (2017), "Protecting tourism labor? Sustainable labels and private governance", GeoJournal, Vol. 82 No. 4, pp. 805-821.

Coe, N.M., Dicken, P. and Hess, M. (2008), "Global production networks: realizing the potential", Journal of Economic Geography, Vol. 8 No. 3, pp. 271-295.

Coe, N.M. and Hess, M. (2013), "Global production networks, labour and development", Geoforum, Vol. 44, pp. 4-9.

Coe, N.M., Hess, M., Yeung, H.W.-c., Dicken, P. and Henderson, J. (2004), “'Globalizing' regional development: a global production networks perspective", Transactions of the Institute of British Geographers, Vol. 29 No. 4, pp. 468-484.

Coe, N.M. and Yeung, H.W.-c. (2015), Global Production Networks, Oxford University Press.

Cooke, F.L. (2004), "Foreign firms in China: modelling HRM in a toy manufacturing corporation", Human Resource Management Journal, Vol. 14 No. 3, pp. 31-52.

Davies, R.B. and Vadlamannati, K.C. (2013), "A race to the bottom in labor standards? An empirical investigation”, Journal of Development Economics, Vol. 103, pp. 1-14.

Dhanarajan, S. (2004), "Faster, Longer, Cheaper: The nexus between poor labour standards and supply-chain management in the apparel industry", European Retail Digest, No. 43, pp. 43-46.

Donaghey, J., Reinecke, J., Niforou, C. and Lawson, B. (2014), "From Employment Relations to Consumption Relations: Balancing Labor Governance in Global Supply Chains", Human Resource Management, Vol. 53 No. 2, pp. 229-252.

Ebert, F.C. (2016), "Labour provisions in EU trade agreements. What potential for channelling labour standards-related capacity building?", International Labour Review, Vol. 155 No. 3, pp. 407-433. 
Fan, D., Xia, J., Zhang, M.M., Zhu, C.J. and Li, Z. (2016), “The paths of managing international human resources of emerging market multinationals: Reconciling strategic goal and control means", Human Resource Management Review, Vol. 26 No. 4, pp. 298-310.

Fontana, E. and Egels-Zandén, N. (2018), "Non Sibi, Sed Omnibus: Influence of Supplier Collective Behaviour on Corporate Social Responsibility in the Bangladeshi Apparel Supply Chain", Journal of Business Ethics.

Frenkel, S.J. (2001), "Globalization, Athletic Footwear Commodity Chains and Employment Relations in China”, Organization Studies, Vol. 22 No. 4, pp. 531-562.

Greer, I. and Hauptmeier, M. (2016), "Management Whipsawing”, ILR Review, Vol. 69 No. 1, pp. 2952.

Hafner-Burton, E.M. and Tsutsui, K. (2005), "Human Rights in a Globalizing World. The Paradox of Empty Promises", American Journal of Sociology, Vol. 110 No. 5, pp. 1373-1411.

He, G. and Perloff, J.M. (2013), “Does Customer Auditing help Chinese Workers?”, Industrial \& Labor Relations Review, Vol. 66 No. 2, pp. 511-524.

Hermes EOS (2017), "Modern slavery: The true cost of cobalt mining”, available at: https://www.hermes-investment.com/ukw/wp-content/uploads/sites/80/2017/11/Hermes-ModernSlavery-Take-Note-Cobalt.pdf (accessed 27 June 2019).

Hofstede, G. (2011), "Dimensionalizing Cultures. The Hofstede Model in Context", available at: https://scholarworks.gvsu.edu/orpc/vol2/iss1/8/ (accessed 27 June 2019).

Homburg, C., Stierl, M. and Bornemann, T. (2013), "Corporate Social Responsibility in Business-toBusiness Markets. How Organizational Customers Account for Supplier Corporate Social Responsibility Engagement", Journal of Marketing, Vol. 77 No. 6, pp. 54-72.

Human Rights Watch (2019), "Hidden Chains. Rights Abuses and Forced Labor in Thailand's Fishing Industry", available at: https://www.hrw.org/report/2018/01/23/hidden-chains/rights-abuses-andforced-labor-thailands-fishing-industry\#_ftn1.

Humphrey, J. and Schmitz, H. (2002), "How does insertion in global value chains affect upgrading in industrial clusters?”, Regional Studies, Vol. 36 No. 9, pp. 1017-1027.

Huq, F.A., Zorzini, M. and Stevenson, M. (2014), "Social sustainability in developing country suppliers. An exploratory study in the ready made garments industry of Bangladesh", International Journal of Operations \& Production Management, Vol. 34 No. 5, pp. 610-638.

Jackson, S.E. and Schuler, R.S. (1995), "Understanding human resource management in the context of organizations and their environments", Annual review of psychology, Vol. 46 No. 1, pp. 237-264.

Jackson, S.E., Schuler, R.S. and Jiang, K. (2014), “An Aspirational Framework for Strategic Human Resource Management”, The Academy of Management Annals, Vol. 8 No. 1, pp. 1-56.

Jackson, T. (2015), "Cross-cultural human resource issues in emerging markets", in Horwitz, F.M. and Budhwar, P.S. (Eds.), Handbook of human resource management in emerging markets, Edward Elgar, Cheltenham, pp. 42-67.

Jayasinghe, M. (2016), "The Operational and Signaling Benefits of Voluntary Labor Code Adoption: Reconceptualizing the Scope of Human Resource Management in Emerging Economies", Academy of Management Journal, Vol. 59 No. 2, pp. 658-677.

Jiang, B., Talluri, S. and Yao, T. (2012), "Improving supplier's situation through supplier cooperation. The case of Xintang jeans town”, International Journal of Production Economics, Vol. 139 No. 2, pp. 431-437.

Kerr, C., Dunlop, J.T., Harbison, F.H. and Myers, C.A. (1960), Industrialism and Industrial Man, Harvard University Press, Cambridge, MA.

Khara, N. and Lund-Thomsen, P. (2012), "Value Chain Restructuring, Work Organization and Labour Outcomes in Football Manufacturing in India”, Competition \& Change, Vol. 16 No. 4, pp. 261280. 
Khattak, A., Haworth, N., Stringer, C. and Benson-Rea, M. (2017), "Is social upgrading occurring in South Asia's apparel industry?", critical perspect on int bus, Vol. 13 No. 3, pp. 226-243.

Knorringa, P. and Nadvi, K. (2016), "Rising Power Clusters and the Challenges of Local and Global Standards", Journal of Business Ethics, Vol. 133 No. 1, pp. 55-72.

Knorringa, P. and Pegler, L.J. (2006), "Globalisation, Firm Upgrading and Impacts on Labour", Tijdschrift voor Economische en Sociale Geografie, Vol. 97 No. 5, pp. 470-479.

Lawler, J.J., Chen, S.-j., Wu, P.-C., Bae, J. and Bai, B. (2011), "High-performance work systems in foreign subsidiaries of American multinationals. An institutional model", Journal of International Business Studies, Vol. 42 No. 2, pp. 202-220.

Lee, J. and Gereffi, G. (2015), "Global value chains, rising power firms and economic and social upgrading”, critical perspectives on international business, Vol. 11 No. 3/4, pp. 319-339.

Levitt, T. (1983), "The globalization of the markets", Harvard Business Review, No. 3, pp. 92-102.

Locke, R., Qin, F. and Brause, A. (2007), “Does Monitoring Improve Labor Standards?”, Industrial \& Labor Relations Review, Vol. 61 No. 1, pp. 3-31.

Locke, R. and Romis, M. (2007), "Improving Work Conditions in a Global Supply Chain", MIT Sloan Management Review, Vol. 48 No. 2, pp. 54-62.

Locke, R.M., Rissing, B.A. and Pal, T. (2013), "Complements or Substitutes? Private Codes, State Regulation and the Enforcement of Labour Standards in Global Supply Chains", British Journal of Industrial Relations, Vol. 51 No. 3, pp. 519-552.

Locke, R.M. and Romis, M. (2010), “The promise and perils of private voluntary regulation: Labor standards and work organization in two Mexican garment factories", Review of International Political Economy, Vol. 17 No. 1, pp. 45-74.

Lund-Thomsen, P., Lindgreen, A. and Vanhamme, J. (2016), "Industrial Clusters and Corporate Social Responsibility in Developing Countries. What We Know, What We do not Know, and What We Need to Know", Journal of Business Ethics, Vol. 133 No. 1, pp. 9-24.

Lund-Thomsen, P., Nadvi, K., Chan, A., Khara, N. and Xue, H. (2012), "Labour in Global Value Chains. Work Conditions in Football Manufacturing in China, India and Pakistan”, Development and Change, Vol. 43 No. 6, pp. 1211-1237.

MacIntosh, M. (2013), "Institutional influences on firm level HRM: some evidence from the Vietnamese garment and footwear sectors”, Asia Pacific Journal of Human Resources, Vol. 51 No. 2, pp. 228-247.

Malik, A.N. (2007), "Stakeholders' perceptions of Corporate Social Responsibility (CSR): Case studies from Bangladesh and Pakistan”, Dissertation, Urban Planning and Environmental Management, The University of Hong Kong, Hong Kong, December 2007.

Mares, R. (2010), "The Limits of Supply Chain Responsibility: A Critical Analysis of Corporate Responsibility Instruments”, Nordic Journal of International Law, Vol. 79 No. 2, pp. 193-244.

Mayer, F. and Gereffi, G. (2010), "Regulation and Economic Globalization: Prospects and Limits of Private Governance", Business and Politics, Vol. 12 No. 3, pp. 1-25.

Merk, J. (2014), "The Rise of Tier 1 Firms in the Global Garment Industry: Challenges for Labour Rights Advocates", Oxford Development Studies, Vol. 42 No. 2, pp. 277-295.

Metters, R. (2017), “Gender and operations management”, Cross Cultural \& Strategic Management, Vol. 24 No. 2, pp. 350-364.

Nadvi, K. and Raj-Reichert, G. (2015), "Governing health and safety at lower tiers of the computer industry global value chain”, Regulation \& Governance, Vol. 9 No. 3, pp. 243-258.

Nadvi, K. and Wältring, F. (2002), "Making sense of global standards", available at: http://citeseerx.ist.psu.edu/viewdoc/download;jsessionid=B7C6D990B8496646A23EAB404D1C7 EA3?doi=10.1.1.476.6281\&rep=rep1\&type=pdf (accessed 27 June 2019). 
Ngai, P. (2005), "Global Production, Company Codes of Conduct, and Labor Conditions in China: A Case Study of Two Factories", The China Journal, Vol. 54 No. 2, pp. 101-113.

Oka, C. (2010), "Accounting for the Gaps in Labour Standard Compliance: The Role of ReputationConscious Buyers in the Cambodian Garment Industry", European Journal of Development Research, Vol. 22 No. 1, pp. 59-78.

Perry, P., Wood, S. and Fernie, J. (2015), "Corporate Social Responsibility in Garment Sourcing Networks. Factory Management Perspectives on Ethical Trade in Sri Lanka”, Journal of Business Ethics, Vol. 130 No. 3, pp. 737-752.

Ponte, S. and Sturgeon, T. (2014), "Explaining governance in global value chains. A modular theorybuilding effort", Review of international political economy: RIPE, Vol. 21 No. 1, pp. 195-223.

Porteous, A.H., Rammohan, S.V. and Lee, H.L. (2015), "Carrots or Sticks? Improving Social and Environmental Compliance at Suppliers Through Incentives and Penalties”, Production and Operations Management, Vol. 24 No. 9, pp. 1402-1413.

Posthuma, A. (2010), Beyond "Regulatory Enclaves": Challenges and Opportunities to Promote Decent Work in Global Production Networks, available at: https://www.ilo.org/legacy/english/protection/travail/pdf/rdwpaper43c.pdf (accessed 27 June 2019).

Prentice, G. (1990), "Adapting management style for the organization of the future", Personnel Management, Vol. 22 No. 6, pp. 58-62.

Punia, M. and Sharma, B. (2015), "A Comprehensive Review of Factors Influencing HRM Practices in Manufacturing", Journal of Management Engineering and Information Technology (JMEIT), Vol. 2 No. 2, pp. 21-29.

Ralston, D.A. (2008), “The Crossvergence Perspective: Reflections and Projections”, Journal of International Business Studies, Vol. 39 No. 1, pp. 27-40.

Reiche, B.S., Lee, Y.-t. and Quintanilla, J. (2012), “Cultural perspectives on comparative HRM”, in Brewster, C. and Mayrhofer, W. (Eds.), Handbook of research on comparative human resource management, Elgar original reference, Edward Elgar, Cheltenham, pp. 51-68.

Rodgers, G. (2007), "Decent Work, Social Inclusion, and Development", Indian Journal of Human Development, Vol. 1 No. 1, pp. 21-32.

Ronconi, L. (2010), "Enforcement and Compliance with Labor Regulations in Argentina", ILR Review, Vol. 63 No. 4, pp. 719-736.

Rossi, A. (2015), "Better Work. Harnessing incentives and influencing policy to strengthen labour standards compliance in global production networks", Cambridge Journal of Regions, Economy and Society, Vol. 8 No. 3, pp. 505-520.

Sartor, M., Orzes, G., Di Mauro, C., Ebrahimpour, M. and Nassimbeni, G. (2016), "The SA8000 social certification standard. Literature review and theory-based research agenda", International Journal of Production Economics, Vol. 175 No. May, pp. 164-181.

Schrank, A. (2013), "From disguised protectionism to rewarding regulation. The impact of traderelated labor standards in the Dominican Republic", Regulation \& Governance, Vol. 7 No. 3, pp. 299-320.

Schuster, M. and Maertens, M. (2016), "Do private standards benefit workers in horticultural export chains in Peru?", Journal of Cleaner Production, Vol. 112 No. 4, pp. 2392-2406.

Scott, W.R. (2013), Institutions and Organizations: Ideas, Interests, and Identities, 4th ed., SAGE Publications, Los Angeles, CA.

Sels, L., Winne, S. de, Delmotte, J., Maes, J., Faems, D. and Forrier, A. (2006), "Linking HRM and Small Business Performance. An Examination of the Impact of HRM Intensity on the Productivity and Financial Performance of Small Businesses”, Small Business Economics, Vol. 26 No. 1, pp. 83-101. 
Sheehan, M. (2014), "Human resource management and performance. Evidence from small and medium-sized firms", International Small Business Journal, Vol. 32 No. 5, pp. 545-570.

Siroën, J.-M. (2013), "Labour provisions in preferential trade agreements. Current practice and outlook", International Labour Review, Vol. 152 No. 1, pp. 85-106.

Soundararajan, V. and Brown, J.A. (2014), "Voluntary Governance Mechanisms in Global Supply Chains: Beyond CSR to a Stakeholder Utility Perspective", Journal of Business Ethics, Vol. 134 No. 1, pp. 1-20.

Soundararajan, V., Spence, L.J. and Rees, C. (2018), "Small Business and Social Irresponsibility in Developing Countries. Working Conditions and "Evasion" Institutional Work", Business \& Society, Vol. 57 No. 7, pp. 1301-1336.

Sparrow, P., Schuler, R.S. and Jackson, S.E. (1994), "Convergence or divergence: human resource practices and policies for competitive advantage worldwide", International Journal of Human Resource Management, Vol. 5 No. 2, pp. 267-299.

Stahl, G.K. and Bjorkman, I. (2006), Handbook of Research in International Human Research Management, Elgar original reference, Edward Elgar Publishing, Cheltenham.

Stallings, B. (2010), "Globalization and Labor in Four Developing Regions: An Institutional Approach", Studies in Comparative International Development, Vol. 45 No. 2, pp. 127-150.

Standing, G. (1999), "Global feminization through flexible labor: A theme revisited", World Development, Vol. 27 No. 3, pp. 583-602.

Stigzelius, I. and Mark-Herbert, C. (2009), “Tailoring corporate responsibility to suppliers: Managing SA8000 in Indian garment manufacturing”, Scandinavian Journal of Management, Vol. 25 No. 1, pp. $46-56$.

Suchman, M.C. (1995), "Managing Legitimacy. Strategic and Institutional Approaches", The Academy of Management Review, Vol. 20 No. 3, pp. 571-610.

Tjandraningsih, I. (2013), "State-Sponsored Precarious Work in Indonesia", American Behavioral Scientist, Vol. 57 No. 4, pp. 403-419.

Toffel, M.W., Short, J.L. and Ouellet, M. (2015), "Codes in context: How states, markets, and civil society shape adherence to global labor standards", Regulation \& Governance, Vol. 9 No. 3, pp. 205-223.

Tokatli, N., Wrigley, N. and Kizilgün, Ö. (2008), "Shifting global supply networks and fast fashion. Made in Turkey for Marks \& Spencer”, Global Networks, Vol. 8 No. 3, pp. 261-280.

Tsogas, G. (2001), Labor regulation in a global economy, Issues in work and human resources, M.E. Sharpe, Armonk, NY.

UN (2015), "Goal 8: Promote inclusive and sustainable economic growth, employment and decent work for all", available at: https://www.un.org/sustainabledevelopment/economic-growth/ (accessed 27 June 2019).

van Marrewijk, M. (2003), "Concepts and Definitions of CSR and Corporate Sustainability. Between Agency and Communion”, Journal of Business Ethics, Vol. 44 No. 2, pp. 95-105.

Vogel, D. (2008), "Private Global Business Regulation”, Annual Review of Political Science, Vol. 11 No. 1, pp. 261-282.

Wilhelm, M.M., Blome, C., Bhakoo, V. and Paulraj, A. (2016), "Sustainability in multi-tier supply chains: Understanding the double agency role of the first-tier supplier", Journal of Operations Management, Vol. 41 No. 1, pp. 42-60.

Winchester, N.J. and Bailey, N. (2012), "The return of cultural dopes? Cultural explanations and the problem of agency”, available at: http://oro.open.ac.uk/40013/6/BAM2012\%202250.pdf (accessed 27 June 2019). 
Wood, G. and Horwitz, F.M. (2015), "Theories and institutional approaches to HRM and employment relations in selected emerging markets", in Horwitz, F.M. and Budhwar, P.S. (Eds.), Handbook of human resource management in emerging markets, Edward Elgar, Cheltenham, pp. 19-41.

Wood, G., Psychogios, A., Szamosi, L.T. and Collings, D.G. (2012), "Institutional approaches to comparative HRM", in Brewster, C. and Mayrhofer, W. (Eds.), Handbook of research on comparative human resource management, Elgar original reference, Edward Elgar, Cheltenham, pp. $27-50$.

World Bank (2013), Opening Doors: Gender Equality and Development in the Middle East and North Africa, Washington DC, USA.

Yang, Y. and Gallagher, M. (2017), "Moving In and Moving Up? Labor Conditions and China's Changing Development Model", Public Administration \& Development, Vol. 37 No. 3, pp. 160 175.

Yeung, H.W.-c. and Coe, N.M. (2015), "Toward a Dynamic Theory of Global Production Networks", Economic Geography, Vol. 91 No. 1, pp. 29-58.

$\mathrm{Yu}, \mathrm{X}$. (2015), "Upholding labour standards through corporate social responsibility policies in China", Global Social Policy, Vol. 15 No. 2, pp. 167-187. 